\title{
Maternal Immune Activation during Gestation Interacts with Disc1 Point Mutation to Exacerbate Schizophrenia-Related Behaviors in Mice
}

\author{
Tatiana V. Lipina, ${ }^{1}$ Clement Zai, ${ }^{2}$ Daniela Hlousek, ${ }^{2}$ John C. Roder, ${ }^{1,3}$ and Albert H.C. Wong ${ }^{2,4}$ \\ ${ }^{1}$ Samuel Lunenfeld Research Institute at Mount Sinai Hospital, Toronto, Ontario, M5G 1X5, Canada, ${ }^{2}$ Centre for Addiction and Mental Health, Campbell \\ Family Mental Health Research Institute, Toronto, Ontario, M5T 1R8, Canada, ${ }^{3}$ University of Toronto, Departments of Medical Biophysics and Molecular \\ and Medical Genetics, Toronto, Ontario, M5S 1A1, Canada, and ${ }^{4}$ Department of Psychiatry, Faculty of Medicine, University of Toronto, Toronto, Ontario, \\ Canada, M5S 1A1
}

Schizophrenia is thought to result from interactions between susceptible genotypes and environmental risk factors. DISC1 is an important gene for schizophrenia and mood disorders based on both human and animal studies. In the present study we sought to investigate interactions between two distinct point mutations in the mouse Disc1 gene (L100P and Q31L) and maternal immune activation (MIA) during pregnancy with polyinosinic:polycytidylic acid (polyI:C). PolyI:C given at $5 \mathrm{mg} / \mathrm{kg}$ impaired cognitive and social behavior in both wild-type (WT) and Disc1-Q31L ${ }^{+/-}$offspring, and reduced prepulse inhibition at 16 but not 8 weeks of age. Disc1-L100P ${ }^{+/-}$mutants were more sensitive to MIA than WT or Disc1-Q31L ${ }^{+/-}$mice. Interleukin-6 (IL-6) is a critical cytokine for mediating the behavioral and transcriptional effects of polyI:C. We found a more pronounced increase of IL-6 in response to polyI:C in fetal brain in Disc1-L100P ${ }^{+/-}$ mice compared with WT or Disc1-Q31L ${ }^{+/-}$mice. Coadministration of an anti-IL-6 antibody with polyI:C reversed schizophrenia-related behavioral phenotypes in Disc1-L100 ${ }^{+/-}$mice. In summary, we found specific interactions between discrete genetic (Disc1-L100 ${ }^{+/-}$) and environmental factors (MIA) that exacerbate schizophrenia-related phenotypes. IL-6 may be important in the pathophysiology of this interaction.

\section{Introduction}

It is widely acknowledged that genes and environmental factors act together to increase the risk of neuropsychiatric disorders, including schizophrenia. An interaction between a susceptibility gene and infection could be shown by a differential effect of prenatal infection on the risk of developing schizophrenia, depending on genotype. A recent study found that prenatal exposure to pyelonephritis results in a fivefold increase in the risk of schizophrenia among individuals with a family history of psychosis compared with those with no family history (Clarke et al., 2009). If all types of infections during pregnancy are considered, approximately one-third of schizophrenia cases could be attributed to prenatal infection (Brown and Derkits, 2010).

Maternal infection during pregnancy is relatively common (Longman and Johnson, 2007) but not all offspring of infected

\footnotetext{
Received Jan. 8, 2013; revised Feb. 14, 2013; accepted March 20, 2013.

Author contributions: T.V.L., J.C.R., and A.H.C.W. designed research; T.V.L., C.Z., and D.H. performed research; T.V.L., C.Z., and D.H. analyzed data; T.V.L., J.C.R., and A.H.C.W. wrote the paper.

This work was supported by a National Alliance for Research on Schizophrenia and Depression Independent Investigator Award from the Brain and Behavior Research Foundation (A.H.C.W.), a Canadian Institutes of Health Research Clinician-Scientist Fellowship (A.H.C.W.), and an Ontario Mental Health Foundation Mid-Career Fellowship (A.H.C.W.).

The authors declare no competing financial interests

Correspondence should be addressed to Dr. Albert H.C. Wong, Centre for Addiction and Mental Health, 250 College Street, Toronto, Ontario, M5T 1R8, Canada. E-mail: albert.wong@utoronto.ca.

DOI:10.1523/JNEUROSCI.0091-13.2013

Copyright $\odot 2013$ the authors $\quad 0270-6474 / 13 / 337654-13 \$ 15.00 / 0$
}

mothers develop schizophrenia (Selten et al., 2010), suggesting that maternal immune activation (MIA) must interact with genes to produce psychiatric illness. Although a considerable number of vulnerability genes for schizophrenia have been identified, only a few have been replicated (Harrison and Weinberger, 2005; Riley and Kendler, 2006). Disrupted-In-Schizophrenia-1 (DISC1) is a prominent schizophrenia susceptibility gene, which regulates progenitor cell proliferation, migration, and differentiation (Chubb et al., 2008; Jaaro-Peled et al., 2009; Brandon and Sawa, 2011). Recent studies have shown interactions between MIA and DISC1, using transgenic mice expressing a dominant-negative DISC1 (DN-DISC1) (Ibi et al., 2010) and a mouse model with inducible expression of mutant human DISC1 (mhDISC1) (Abazyan et al., 2010). MIA triggered behavioral and cellular alterations related to schizophrenia in adult DN-DISC1 offspring without effect on WT mice (Ibi et al., 2010; Nagai et al., 2011). The combination of MIA with postnatal expression of hmDISC1 resulted in anxiousdepressive phenotypes (Abazyan et al., 2010). Although these two studies used different approaches to MIA and different DISC1 modifications, they illustrate the interactions between DISC1 and the maternal immune system during development.

We had created point mutant mouse lines, Disc1-L100P and Disc1-Q31L (Clapcote et al., 2007) that showed schizophrenia- or depression-related phenotypes, respectively (Lipina et al., 2010, 2011, 2012; 2013a; Lee et al., 2011). For both Disc1 mutations, the heterozygous mutants had very mild behavioral alterations (Clapcote et al., 2007). Thus, we hypothesized that the combina- 
tion of MIA with a single copy of a Discl mutation would be a useful model of gene $X$ environment interactions in psychiatric disease. More specifically, we predicted that because MIA is a strong epidemiological risk factor for schizophrenia but not depression, that heterozygous Disc1-L100P ${ }^{+/-}$mutants would be more sensitive to effects of MIA.

Therefore, we applied MIA to heterozygous Disc1 mutant females on gestational day 9 (GD9) according to the literature (Meyer et al., 2005) and assessed behavior in adult offspring. Indeed, the Disc1-L100P, but not Disc1-Q31L, mutation increases sensitivity to MIA and exacerbates schizophrenia-related behavior. Finally, given that interleukin-6 (IL-6) was identified as a key cytokine for mediating the behavioral and transcriptional alterations in polyinosinic:polycytidylic acid (polyI:C)-treated offspring, we investigated whether anti-IL-6 antibody could block the effects of polyI:C in Disc1-L100P mice, similar to a previous study (Smith et al., 2007).

\section{Materials and Methods}

Animals. Disc1-L100P and Disc1-Q31L heterozygous mice (Disc1${\mathrm{L} 100 \mathrm{P}^{+/-} \text {and Disc1-Q31L }}^{+/-}$, respectively) and their wild-type (WT) littermates were used throughout the study. The generation of the Disc1 mutant mice has been described previously (Clapcote et al., 2007). The mice used in the current experiments had been backcrossed for six to eight generations on a C57BL/6J background. Littermates (males and females) were generated by cross-breeding of WT, Disc1-L100P ${ }^{+/-}$, or Disc1-Q31L ${ }^{+/-}$female mice with C57BL/6J male mice. All animals were housed five per cage under controlled temperature $\left(21 \pm 1^{\circ} \mathrm{C}\right)$, lighting (lights on: 7:00 A.M.-7:00 P.M.), and humidity (50-60\%) with food ad libitum (Purina mouse chow). All animal procedures were approved by the Animal Management Committee of Mount Sinai Hospital and conducted in accordance with the requirements of the Province of Ontario Animals for Research Act 1971 and the Canadian Council on Animal Care.

For the purpose of the MIA during pregnancy, pregnant females received either a single injection of polyI:C $(2.5 \mathrm{mg} / \mathrm{kg}$ or $5 \mathrm{mg} / \mathrm{kg})$ or PBS (sterile pyrogen-free PBS, $0.9 \% \mathrm{NaCl}$ ) on GD9 (Meyer et al., 2005). Two different doses of polyI:C were chosen based on the literature (Meyer et al., 2005; Vuillermot et al., 2012) and our findings as described below.

PolyI:C injection. PolyI:C (potassium salt) (Sigma-Aldrich) was dissolved in PBS. The dosage was calculated based on the pure form. Intravenous tail vein injections were performed under mild physical constraint. All solutions were freshly prepared on the day of administration and injected at a volume of $5 \mathrm{ml} / \mathrm{kg}$.

Measurement of IL-6 levels. Pregnant females were given injections of PBS or polyI:C $(2.5 \mathrm{mg} / \mathrm{kg}$ or $5.0 \mathrm{mg} / \mathrm{kg})$ on GD 9 and were killed by cervical dislocation $6 \mathrm{~h}$ after the treatment. The uterus was removed, washed out, and transferred to a Petri dish with ice-cold PBS. Each fetus was individually extracted and the separated fetal head was rapidly placed in liquid nitrogen and stored at $-80^{\circ} \mathrm{C}$ until analysis.

Fetal brain samples were placed in radioimmunoprecipitation assay lysis buffer (Santa Cruz Biotechnology) containing Tris-buffered saline, $1 \%$ Nonider P-40, 0.5\% sodium deoxycholate, $0.1 \%$ SDS, $0.004 \%$ sodium azide, PMSF, sodium-orthovanadate, and protease inhibitor mixture (Sigma), followed by centrifugation at $12,000 \mathrm{rpm}$ for $20 \mathrm{~min}$ at $4^{\circ} \mathrm{C}$. The IL-6 level was assessed by ELISA (R\&D Systems), according to the manufacturer' instructions. The FLUOstar Optima reader (BMG Labtech) was used to determine the concentration of IL-6. The data were normalized to protein concentration in the sample, as determined by Bradford assay (Protein Assay; Bio-Rad).

Cytokine blocking: experimental groups. Mice (WT, Disc1-L100 ${ }^{+/-}$) were given intravenous tail injections of $2.5 \mathrm{mg} / \mathrm{kg}$ polyI:C freshly dissolved in PBS. Some of the mice were given coinjections of $100 \mu \mathrm{g}$ of cytokine-neutralizing antibody targeted against IL-6 (anti-IL-6; rat IgG1; R\&D Systems), freshly dissolved in $200 \mu$ l PBS (Smith et al., 2007). Control mice were given injections of $200 \mu \mathrm{l}$ of PBS.

Four groups of mice were generated for Experiment 1: (1) PBS-treated WT (PBS/WT), (2) polyI:C 5 mg/kg-treated WT (Poly-5/WT), (3) PBS- treated Disc1-Q31L ${ }^{+/-}$(PBS/Disc1-Q31L $\left.{ }^{+/-}\right)$, and (4) polyI:C $5 \mathrm{mg} /$ kg-treated Disc1-Q31L ${ }^{+/-}$(Poly-5/Disc1-Q31L $\left.{ }^{+/-}\right)$. Another four groups were used in Experiment 2: (1) PBS-treated WT (PBS/WT), (2) polyI:C $2.5 \mathrm{mg} / \mathrm{kg}$-treated WT (Poly-2.5/WT), (3) PBS-treated Discl\left.${\mathrm{L} 100 \mathrm{P}^{+/-}(\mathrm{PBS} / \text { Disc1-L100P }}^{+/-}\right)$, and (4) polyI:C $2.5 \mathrm{mg} / \mathrm{kg}$-treated

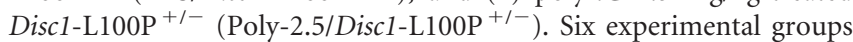
were used in Experiment 3: (1) PBS-treated WT (PBS/WT), (2) polyI:C 2.5 $\mathrm{mg} / \mathrm{kg}$-treated WT (Poly-2.5/WT), (3) anti-IL-6 + polyI:C $2.5 \mathrm{mg} / \mathrm{kg}$ treated WT (anti-IL-6 + Poly-2.5/WT), (4) PBS-treated Disc1-L100P ${ }^{+/-}$ (PBS/Disc1-L100P ${ }^{+-}$), (5) polyI:C $2.5 \mathrm{mg} / \mathrm{kg}_{\text {-treated Disc1-L100P }}+$ (Poly-2.5/Disc1-L100P ${ }^{+/-}$), and (6) anti-IL-6 + polyI:C $2.5 \mathrm{mg} / \mathrm{kg}$-treated Disc1-L100P ${ }^{+/-}$(anti-IL-6 + Poly-2.5/Disc1-L100P ${ }^{+/-}$).

Behavioral studies. Behavioral tests were done between 9:00 A.M. and 4:00 P.M. The behavioral experiments started when the mice were 7-8 weeks of age for Experiment 1, and at 14-15 weeks of age for Experiments 2-3 due to the prepulse inhibition (PPI) findings obtained in Experiment 1. Tests were conducted in the following order: elevated plus-maze (EPM), open field (OF), PPI of the acoustic startle response (ASR), object recognition, social affiliation/recognition, forced swim test (FST), and latent inhibition (LI). There was a 3-5 d interval between tests. Before all experiments, mice were left undisturbed in the testing room for $30 \mathrm{~min}$ to allow acclimation. In the LI experiment, water deprivation was initiated $24 \mathrm{~h}$ before the training period and continued throughout the experiment. Water access was limited and was monitored by measuring weight loss. Mice had additional daily access to water for $1 \mathrm{~h}$ in their home cages after the experiment. Only male mice were used in the social affiliation/ recognition test. The behavioral equipment was cleaned with $70 \%$ ethanol between mice to remove residual odors.

EPM. The test apparatus was made as previously described (Clapcote et al., 2007). The maze consisted of two open arms $(25 \times 5 \mathrm{~cm})$, two enclosed arms $(25 \times 5 \times 30 \mathrm{~cm})$, and a central platform $(5 \times 5 \mathrm{~cm})$ arranged so that similar arms were opposite each other and at right angles to dissimilar arms. The arms and the floor were constructed from opaque Plexiglas material and were elevated $50 \mathrm{~cm}$ above the floor. Experiments were conducted in a dimly lit room with 210 lux light intensity on the central platform. The apparatus was cleaned with $70 \%$ ethanol between subjects. Each mouse was placed in the center of the maze $(5 \times 5 \mathrm{~cm})$ facing the closed arm. During a 5 min observation period, the following parameters were recorded: (1) the amount of time spent in open arm, closed arm, and the central platform, expressed as a percentage of total time; (2) total number of entries (defined as four paws into an arm); (3) number of passages from one enclosed arm to another; (4) number of head dips; and (5) number of risk assessments (defined as a mouse located primarily within the closed arm, but with the nose poking out of the arm and apparently scanning the open space for threats), were scored by the observer.

OF. Each mouse was placed in the middle of a directly illuminated ( 120 lux) automated activity cage $\left(41 \mathrm{~cm} \times 41 \mathrm{~cm} \times 33 \mathrm{~cm}^{3}\right)$ (model 7420/ 7430; Ugo Basile) and horizontal and vertical activity was measured for $30 \mathrm{~min}$. The arena was cleaned with $70 \%$ ethanol between mice.

PPI of ASR. PPI was conducted using four sound-attenuated chambers (ENV-022 s; MED Associates), as previously described (Clapcote et al., 2007; Lipina et al., 2010). Pulse-alone trials consisted of a single white noise burst $(120 \mathrm{~dB}, 40 \mathrm{~ms})$. Prepulse + pulse trials (PP69P, PP73P, PP81P) consisted of a prepulse of noise (20 ms at 69,73 , and $81 \mathrm{~dB}$, respectively) followed $100 \mathrm{~ms}$ after prepulse onset by a startle pulse. No-stimulus trials consisted of background noise only ( $65 \mathrm{~dB})$. Sessions were structured as follows: (1) $15 \mathrm{~min}$ acclimation at background noise level; (2) 10 pulse trials; (3) 10 blocks each containing all five trials (pulse, PP69P, PP73P, PP81P, No-stimulus) in pseudorandom order; and (4) 10 pulse trials. The force intensity for each trial was recorded as the startle level. The percentage PPI induced by each prepulse intensity was calculated as $[1-($ startle amplitude on prepulse trial)/(startle amplitude on pulse alone) $]^{\star} 100 \%$.

Object recognition. The spatial discrimination task was performed as previously described (Lipina et al., 2013b) in a transparent Plexiglas OF $\left(41 \times 41 \times 31 \mathrm{~cm}^{3}\right)$. The procedure consisted of three sessions, habituation to objects, test session 1, and test session 2, with 2 min intervals, during which mice were returned to their home cage. Habituation con- 
sisted of four identical plastic objects ( $100 \mathrm{ml}$ beaker) flipped and placed in specific positions near each corner of the $\mathrm{OF}$ ( $5 \mathrm{~cm}$ from corner walls). A mouse was released into the center of the arena and time spent actively exploring the objects, usually by sniffing within $1 \mathrm{~cm}$, was recorded for 15 min using Observer 5.0 software (Noldus Information Technology). Next, the mouse was returned to the home cage and the four objects were reconfigured into a polygon-shaped pattern by moving two displaced objects (DOs) to the center. The remaining two nondisplaced objects (NDO) were left at the same location. After $2 \mathrm{~min}$, a mouse was placed in the center of the OF and time of exploration of the DOs and NDOs were recorded for $5 \mathrm{~min}$ (test session 1) and expressed as a percentage of the total time spent investigating all objects. Afterward, the tested mouse was returned to the home cage for $2 \mathrm{~min}$. During this interval one of the familiar NDOs was replaced by new object (NO) (Rubik's cube; $7.62 \times$ $\left.7.62 \times 7.62 \mathrm{~cm}^{3}\right)$ in the same location and other two DOs were removed. The mouse was returned to the center of the arena for $5 \mathrm{~min}$ (test session 2). Time spent exploring the familiar object (FO) and NO were assessed and expressed as a percentage of the total time spent exploring objects. Objects and the tested apparatus were cleaned by $70 \%$ ethanol between mice.

Social affiliation/recognition. The social behavior in this task was measured as previously described (Clapcote et al., 2007), using a threechambered box. The test mouse was placed in the center chamber with access to the two side chambers. These side chambers contain mesh cylinders that are either empty or have another mouse inside. At the beginning of each experimental session, the test mouse was placed in the central chamber and was allowed to freely explore for $5 \mathrm{~min}$. Next, an unfamiliar mouse (male C57BL/6J; "stranger 1") was placed inside a cylinder in one of the side chambers. The time spent by the test mouse in each outer chamber was recorded over a $10 \mathrm{~min}$ period, to measure general social interest (session 1). Another unfamiliar mouse (male C57BL/6J; "stranger 2") was then placed inside an identical cylinder in the opposite side chamber, and the activity of the test mouse was likewise recorded for a further $10 \mathrm{~min}$, to evaluate social novelty (session 2). The amount of time spent near each cylinder and the number of entries into each chamber were scored using Observer 5.0. The apparatus was cleaned with $70 \%$ ethanol between mice.

FST. The protocol was performed as previously described (Clapcote et al., 2007). Each mouse was released into a transparent plastic cylinder $(25$ $\mathrm{cm}$ height $\times 18 \mathrm{~cm}$ diameter), which contained water at $25^{\circ} \mathrm{C}$. The experiment lasted $6 \mathrm{~min}$, and an observer scored the floating (no limb movement and making only minimal movements to keep the head above the water) in the last $4 \mathrm{~min}$ of the trial using the Observer 5.0 software. Each mouse was allowed to dry after the test, and the water was changed between subjects. Data are expressed as a time of floating (seconds).

$L I$. This was measured in three conditioning chambers (Med Associates) each enclosed in a melamine, sound-attenuating chamber (ENV022M) as previously described (Clapcote et al., 2007; Lipina et al., 2010). All events were programmed by MED-PC software. The chambers were cleaned with $70 \%$ ethanol between sessions. Before the beginning of each $\mathrm{LI}$ experiment, water was removed from the cages for $24 \mathrm{~h}$ and mice were then trained to drink in the experimental chamber for $5 \mathrm{~d}, 15 \mathrm{~min}$ per day (pretraining session). On each daily pretraining session, mice were acclimated to the chamber without access to the sipper tube for $5 \mathrm{~min}$; then the guillotine door was opened. Latency to the first lick and number of licks were recorded for $15 \mathrm{~min}$. During pre-exposure and conditioning, access to the bottle was prevented by a guillotine door. The LI procedure was conducted on days 6-9 and consisted of pre-exposure, conditioning, lick retraining, and test sessions. Pre-exposure: the pre-exposed (PE) mice received 40, $85 \mathrm{~dB}$-white noise presentations with an interstimulus interval of $60 \mathrm{~s}$. The nonpre-exposed (NPE) mice were confined to the chamber for an identical period of time without receiving the stimuli. Conditioning: all mice received fear conditioning to the noise stimulus on that day. Two noise-shock pairings were used to produce LI. Five minutes after the beginning of the session, a $10 \mathrm{~s}$ white noise was followed by a 1 s $0.37 \mathrm{~mA}$ foot shock. The noise-shock pairings were given $5 \mathrm{~min}$ apart and after the last pairing, mice were left in the experimental chamber for an additional $5 \mathrm{~min}$. During the test session each mouse was placed in the chamber and when the mouse completed 75 licks, the noise
Table 1. The effect of MIA on anxiety of WT and Disc1-Q31L ${ }^{+/-}$offspring in the EPM

\begin{tabular}{|c|c|c|c|c|}
\hline & WT & & 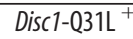 & \\
\hline & $\begin{array}{l}\text { PBS } \\
N=7\end{array}$ & $\begin{array}{l}\text { Polyl:C-5 } \\
N=12\end{array}$ & $\begin{array}{l}\text { PBS } \\
N=9\end{array}$ & $\begin{array}{l}\text { Polyl:C-5 } \\
N=11\end{array}$ \\
\hline Open arms time, \% & $10.6 \pm 3.1$ & $9.6 \pm 3.7$ & $8.9 \pm 3.9$ & $10.2 \pm 3.2$ \\
\hline Central platform time, $\%$ & $27.3 \pm 7.9$ & $26.4 \pm 9.4$ & $25.4 \pm 7.8$ & $28.1 \pm 6.4$ \\
\hline Enclosed arms time, \% & $62.0 \pm 7.9$ & $64.0 \pm 7.2$ & $66.7 \pm 7.3$ & $61.6 \pm 10.2$ \\
\hline Total entries, number & $29.0 \pm 1.9$ & $31.2 \pm 2.9$ & $28.6 \pm 2.1$ & $34.3 \pm 1.5$ \\
\hline Passages, number & $5.7 \pm 0.6$ & $5.2 \pm 0.7$ & $4.9 \pm 0.5$ & $5.3 \pm 0.7$ \\
\hline Head dips, number & $6.1 \pm 1.0$ & $8.2 \pm 1.2$ & $7.3 \pm 1.4$ & $6.9 \pm 0.8$ \\
\hline
\end{tabular}

was presented and lasted until the mouse reached lick 101. Time to first lick, time to complete licks 50-75 (before noise onset: "A" period), and time to complete licks 76-101 (after noise onset: "B" period) were recorded. The degree of lick suppression was calculated as a the ratio $\mathrm{A} /(\mathrm{A}+\mathrm{B})$. A lower suppression score indicates a stronger suppression of drinking. LI consists of lower suppression of drinking (higher suppression ratio) in the PE compared with the NPE mice.

Data analysis. Statistical analyses were completed using Statistica (Statsoft 5.5). Behavioral data were analyzed using ANOVA with polyI:C, genotype and sex as between-subject variables. PPI and motor activity in the OF were analyzed by three-way ANOVAs with repeated measures (prepulse intensities and time intervals). No statistical analyses detected significant sex effects. Therefore, data were combined between sexes. The IL-6 data were analyzed using ANOVA with polyI:C and genotype as between-subject variables. The significant main effects or interactions were followed by Fisher's LSD post hoc comparisons. The significance level used was $p<0.05$.

\section{Results}

\section{Experiment 1}

Effects of MIA by polyI:C at $5 \mathrm{mg} / \mathrm{kg}$ on number of litters and offspring

ANOVA detected a significant effect of polyI:C treatment $\left(F_{(1,24)}=\right.$ 36; $p<0.001)$, genotype $\left(F_{(2,24)}=21 ; p<0.001\right)$, and their interactions $\left(F_{(2,24)}=21 ; p<0.001\right)$ on number of litters and number of offspring, respectively $\left(F_{(1,24)}=27.9 ; p<0.001\right.$, effect of polyI:C; $F_{(2,24)}=19.9 ; p<0.001$, effect of genotype; $F_{(2,24)}=$ $19.7 ; p<0.001$, effect of polyI:C $\times$ genotype interaction). Disc1L100 ${ }^{+/-}$females treated by polyI:C at $5 \mathrm{mg} / \mathrm{kg}$ did not produce any pups, whereas no difference in the amount of offspring was seen between other experimental groups. We did not observe any pups or carcasses left in home cages with pregnant Disc1L100P ${ }^{+/-}$females treated by polyI:C at $5 \mathrm{mg} / \mathrm{kg}$, whereas there was no difference in number of offspring/litter size between polyI:C-treated WT and Disc1-Q31L ${ }^{+/-}$females. Therefore, we reduced the dose and used polyI:C at $2.5 \mathrm{mg} / \mathrm{kg}$ in Experiments 2 and 3.

\section{Effects of MIA by polyI:C at $5 \mathrm{mg} / \mathrm{kg}$ on behavior of Disc1-Q31L ${ }^{+/-}$and WT offspring \\ EPM}

MANOVA did not detect any effect of MIA, genotype, or their interactions on most of the studied parameters in the EPM (Table $1)$. However, there was a main effect of genotype $\left(F_{(1,34)}=3.9\right.$, $p<0.05)$ and MIA $\times$ genotype interactions $\left(F_{(1,34)}=9.2 ; p<\right.$ $0.01)$ on risk assessment. Poly-5/Disc1-Q31L ${ }^{+/-}$offspring scanned the EPM for potential threat more often than PBS/Disc1$\mathrm{Q} 1 \mathrm{~L}^{+/-}$mice $(p<0.05$; Fig. $1 A)$.

\section{FST}

There were no effects of MIA, genotype, or their interactions on duration of floating (Fig. $1 B$; all $p s>0.05$ ). 

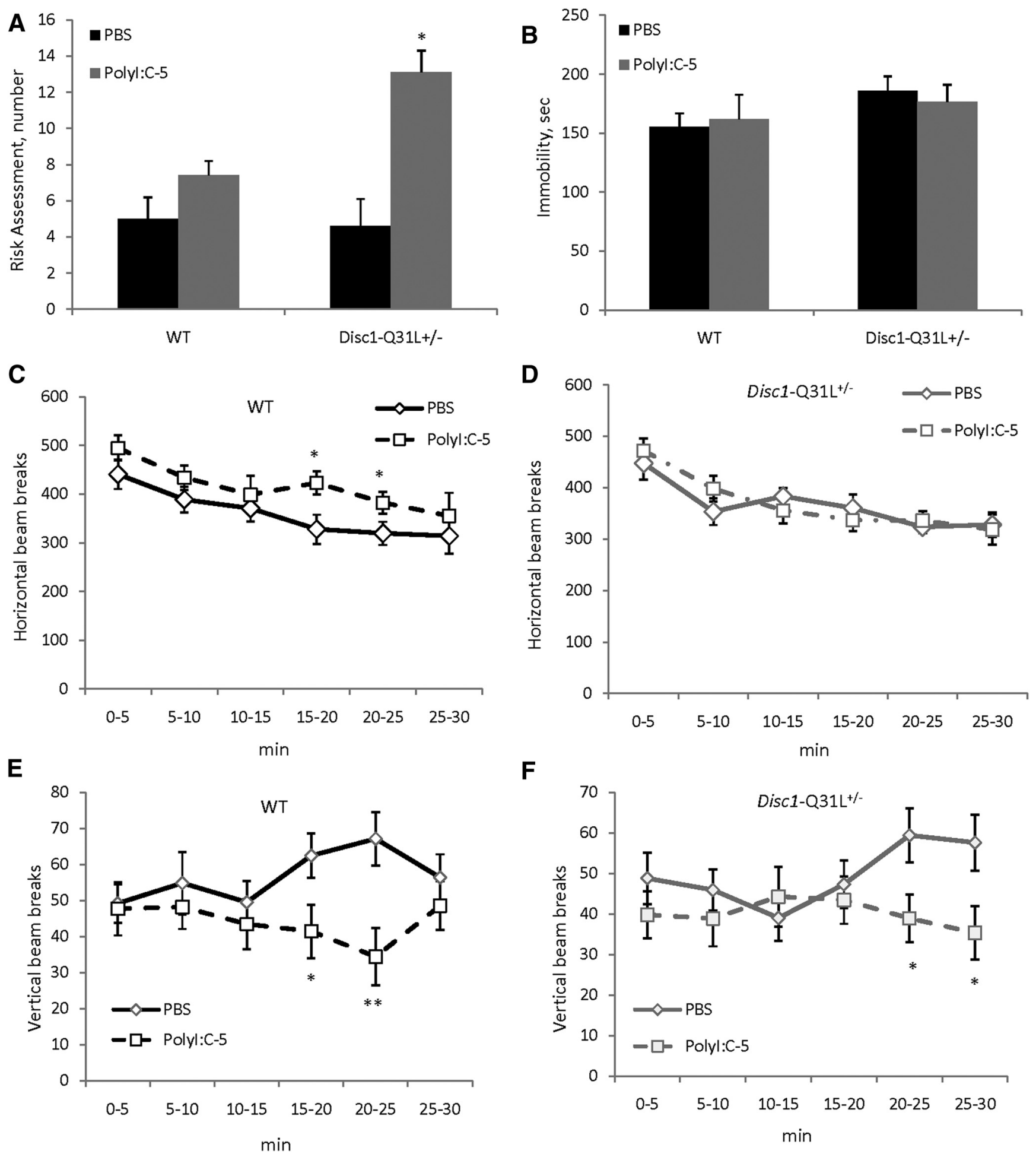

Figure 1. The effects of prenatal immune activation by $5 \mathrm{mg} / \mathrm{kg}$ of polyl:C on anxiety $(\boldsymbol{A})$, behavioral despair $(\boldsymbol{B})$, and horizontal $(\boldsymbol{C}, \boldsymbol{D})$ and vertical activity $(\boldsymbol{E}, \boldsymbol{F})$ in WT and Disc $1-031 \mathrm{~L}{ }^{+/-}$mice. $\boldsymbol{A}$, Adult Disc1-031L ${ }^{+/-}$offspring born to mothers injected with $5 \mathrm{mg} / \mathrm{kg}$ of polyl:( showed more frequent risk assessment in the EPM task ( $n=7-12$ per each group) compared with WT mice, with no effect on the duration of floating in the $\mathrm{FST}(\boldsymbol{B})(\boldsymbol{n}=7-17$ per each group). Mice of both genotypes born to polyl: $(-$-treated mothers showed a significant deficitin exploration, assessed as vertical activity in the $0 \mathrm{~F}(\boldsymbol{E}$, $\boldsymbol{F})$, with mild effect on horizontal activity in WT offspring $(\boldsymbol{C})$ and no effect on Disc $1-031 \mathrm{~L}^{+/-}$mice $(\boldsymbol{D})\left(n=10-17\right.$ per each group). ${ }^{*} p<0.05$; ${ }^{* *} p<0.01$ in comparison with control (offspring born to PBS-treated mothers) within each genotype.

OF

MANOVA detected a main effect of time intervals $\left(F_{(5,255)}=\right.$ $25.9 ; p<0.001)$ and genotype $\times$ MIA interactions $\left(F_{(1,51)}=3.9\right.$; $p<0.05$ ) on horizontal activity. Poly-5/WT mice showed higher levels of ambulation than PBS/WT between the 15 and 25th min- ute (both $p s<0.05$; Fig. $1 C$ ), whereas no effect of MIA was observed on Disc1-Q31L $\mathrm{L}^{+/-}$mice (Fig. 2D). MANOVA found significant effects of genotype $\times \operatorname{MIA}\left(F_{(5,255)}=3.5 ; p<0.01\right)$ and genotype $\times$ MIA $\times$ time interval $\left(F_{(5,255)}=5.9 ; p<0.05\right)$ interactions on vertical activity. Poly-5/WT offspring had less 
A
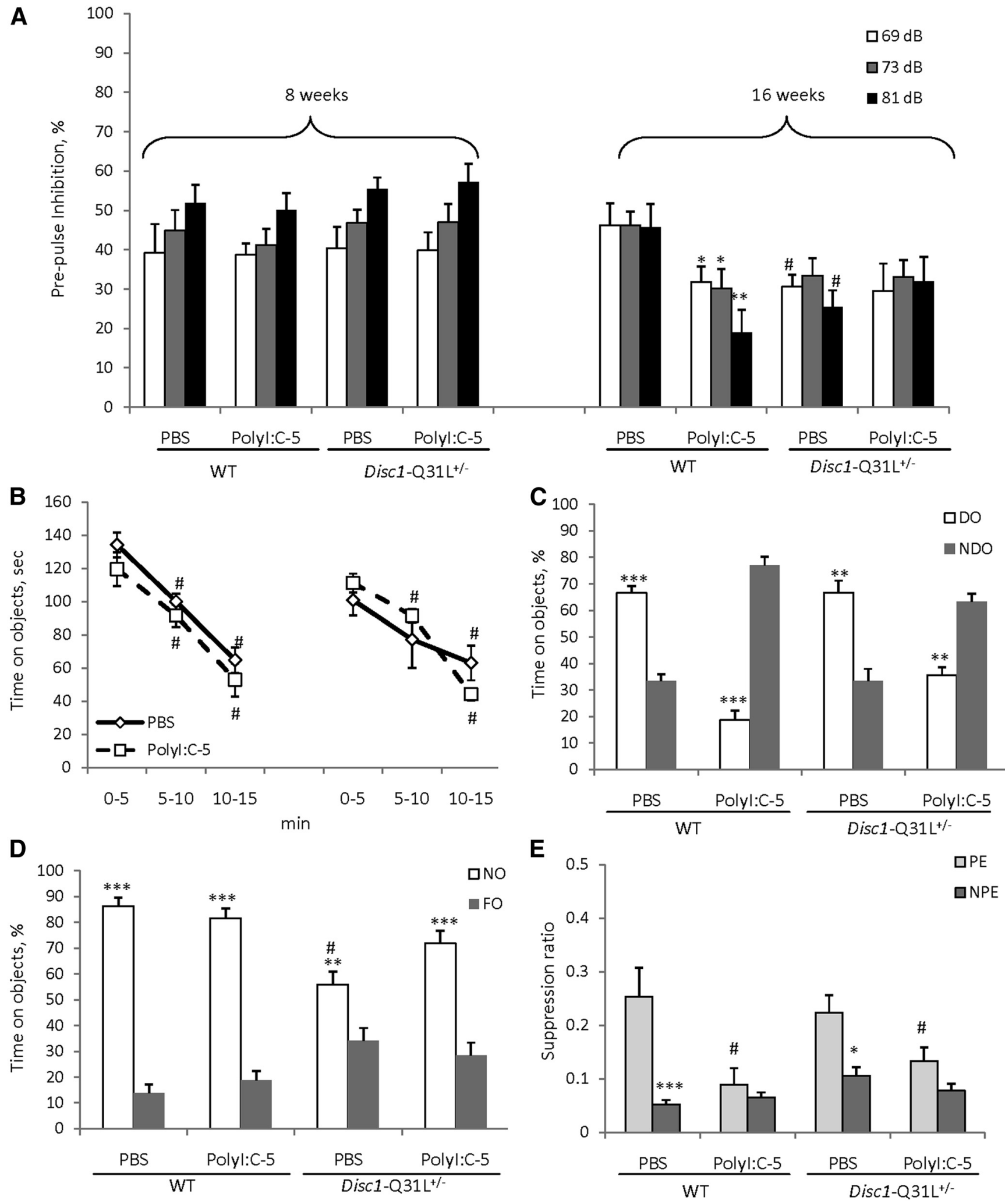

Figure 2. The effects of prenatal immune activation on PPI $(\boldsymbol{A})$, object recognition $(\boldsymbol{B}-\boldsymbol{D})$, and $\mathrm{LI}(\boldsymbol{E})$ in WT and Disc1-031L ${ }^{+/-}$mice. Adult WT offspring of both genotypes born to mothers injected with $5 \mathrm{mg} / \mathrm{kg}$ of polyl:C expressed PPI deficits at 16 weeks but not at 8 weeks of age $(\boldsymbol{A})\left(n=8-19\right.$ per each group). Adult Disc $1-031 \mathrm{~L}^{+/-}$offspring born to mothers either treated by polyl:C or PBS showed PPI deficits ( $n=9-17$ per each group). ${ }^{*} p<0.05$; ${ }^{* *} p<0.01$, in comparison with control mice; ${ }^{*} p<0.05$, in comparison with WT offspring born to PBS-treated dams. $\boldsymbol{B}$, Adult mice of all experimental groups showed similar habituation to objects but immune-challenged offspring of both genotypes had spatial object recognition deficits; ${ }^{\#} p<0.001$, in comparison with the first time interval of the habituation within each experimental group (C). Mice of all experimental groups showed comparable novel object recognition (D). $N=6-12$ per each group; ${ }^{* *} p<$ $0.01 ;{ }^{* * *} p<0.001$, compared with the time spent on either NDO or FO within each experimental group; ${ }^{*} p<0.01$, compared with WT offspring born to PBS-treated dams. E, MIA by $5 \mathrm{mg} / \mathrm{kg}$ of polyl:C disrupted Ll in both WT and Disc1-031L ${ }^{+/-}$offspring. Mean suppression ratios of the PE and NPE mice conditioned with two conditioned stimulus - unconditioned stimulus trials and given 40 pre-exposures $\left(N=6-7\right.$ per each group). ${ }^{*} p<0.05 ;{ }^{* * *} p<0.001$, in comparison with PE within each experimental group; ${ }^{*} p<0.05$, in comparison with $\mathrm{PE}$ control mice for each genotype. 


\begin{tabular}{|c|c|c|c|c|}
\hline & \multicolumn{2}{|l|}{ WT } & \multicolumn{2}{|l|}{ Disc1-031L ${ }^{+1-}$} \\
\hline & PBS & Polyl:C-5 & PBS & Polyl:(-5 \\
\hline \multirow{4}{*}{$\begin{array}{l}\text { Acoustic startle } \\
\text { response }\end{array}$} & \multicolumn{4}{|c|}{8 weeks } \\
\hline & $1029.3 \pm 85.3$ & $1144.2 \pm 89.1$ & $1048.6 \pm 80.9$ & $1027.6 \pm 85.3$ \\
\hline & \multicolumn{4}{|c|}{16 weeks } \\
\hline & $912.5 \pm 86.8$ & $897.5 \pm 92.2$ & $885.0 \pm 94.4$ & $840.9 \pm 82.3$ \\
\hline
\end{tabular}

rearings than PBS-WT during the 15-30th minute of the test ( $p$ s $<0.05$ at $15-20$ th and 25-30th minute; $p<0.01$ at the $20-$ 25th minute) (Fig. $1 E$ ). Poly-5/Disc1-Q31L $\mathrm{L}^{+/-}$mice also had lower vertical activity from the $20-30$ th minute (Fig. $1 F$ ).

PPI

MANOVA found a main effect of prepulses $\left(F_{(2,198)}=5.9, p<\right.$ $0.05)$, age $\left(F_{(1,99)}=62.3, p<0.001\right)$, MIA $\times$ age $\left(F_{(1,99)}=5.3\right.$, $p<0.05)$, and MIA $\times$ genotype $\times$ age $\left(F_{(1,99)}=6.64, p<0.05\right)$ interactions. PolyI:C given at $5 \mathrm{mg} / \mathrm{kg}$ to pregnant females had no effect on PPI of offspring of either genotype at 8 weeks of age, whereas MIA impaired PPI in WT offspring at all three prepulses ( $p$ s $<0.05$ at 69 and $73 \mathrm{~dB}$ and $p<0.01$ at $81 \mathrm{~dB}$ ) (Fig. 2A). PBS/Disc1-Q31L ${ }^{+/-}$mice showed PPI deficits at 69 and $81 \mathrm{~dB}$ at 16 weeks of age $(p s<0.05)$ in comparison with PBS/WT at 16 weeks of age, but MIA had no effect on PPI in Disc1-Q31L ${ }^{+/-}$ offspring (Fig. 2A). MANOVA did not detect any significant effect on startle response in mice of all experimental groups (Table 2).

\section{Object recognition}

MANOVA detected a main effect of time intervals $\left(F_{(2,66)}=82.7\right.$; $p<0.001$ ) during the habituation session, but no effect of genotype, MIA, or any interactions $(p s>0.05)$. Mice in all experimental groups showed gradually declining interest toward objects during the acclimation period (Fig. 2B). MANOVA found a significant effect of $\operatorname{MIA}\left(F_{(1,33)}=3.5, p<0.05\right), \operatorname{MIA} \times \operatorname{DO}\left(F_{(1,33)}=128.1, p<\right.$ $0.001)$, genotype $\times \operatorname{MIA}\left(F_{(1,33)}=5.2, p<0.05\right)$, and MIA $\times$ genotype $\times \mathrm{DO}\left(F_{(1,33)}=5.1, p<0.05\right)$ interactions. PBS/WT and PBS/ Disc1-Q31L ${ }^{+/-}$mice spent significantly more time on DOs than on NDOs $\left(p<0.001\right.$ and $p<0.01$ for WT and Disc1-Q31L ${ }^{+/-}$, respectively), whereas Poly-5/WT and Poly-5/Disc1-Q31L ${ }^{+/-}$offspring preferred NDOs $(p<0.001$ and $p<0.01$ for WT and Disc1Q31 $\mathrm{L}^{+/-}$, respectively; Fig. $2 C$ ). Analysis of the last session revealed a main effect of $\mathrm{NO}\left(F_{(1,33)}=122.8, p<0.001\right)$, genotype $\times \mathrm{NO}$ $\left(F_{(1,33)}=21.7 ; p<0.001\right)$, and MIA $\times$ genotype $\times$ NO $\left(F_{(1,33)}=\right.$ $5.7, p<0.05)$. Mice in all experimental groups were able to detect NOs and spent significantly more time than with FO although PBS/ Disc1-Q31L ${ }^{+/-}$offspring spent less time on NO than PBS/WT $(p<$ 0.01; Fig. 2D).

LI

Animals in all experimental groups did not differ in the A period ( $p s>0.05$; overall A period $=6.9 \mathrm{~s})$. MANOVA found a main effect of pre-exposure $\left(F_{(1,46)}=28.3 ; p<0.001\right)$, MIA $\left(F_{(1,46)}=8.3 ; p<\right.$ $0.01)$, and MIA $\times$ pre-exposure $\left(F_{(1,46)}=7.2 ; p<0.01\right)$ interactions. PBS/WT and PBS/Disc1-Q31L ${ }^{+/-}$offspring expressed LI $(p<$ 0.001 and $p<0.05$, respectively), whereas Poly-5/WT and Poly-5/ Disc1-Q31L ${ }^{+/-}$showed impaired LI (both $p$ 's $\left.>0.05\right)($ Fig. $2 E)$.

\section{Experiment 2 \\ Behavioral effects of MIA by polyI:C at $2.5 \mathrm{mg} / \mathrm{kg}$ on Disc1-L100P ${ }^{+/-}$and WT offspring \\ OF}

MANOVA detected significant effect of time intervals $\left(F_{(5,255)}=\right.$ 19.7; $p<0.001$ ) on horizontal activity, but no other effects
( $p s>0.05)$. Indeed, mice of all experimental groups showed comparable ambulation in the $\mathrm{OF}$, gradually decreasing their motor activity (Fig. $3 A, B$ ). However, MANOVA found a main effect of MIA $\left(F_{(1,39)}=8.3 ; p<0.01\right)$ and MIA $\times$ time intervals $\left(F_{(5,195)}=2.5 ; p<0.05\right)$ on vertical activity. Poly-2.5-WT and Poly-2.5-Disc1-L100 ${ }^{+/-}$significantly reduced vertical activity within each genotype in comparison with corresponding control PBS groups $(p<0.01$ and $p<0.05$ at $15-20$ th and $25-30$ th minutes for WT; and $p s<0.05$ and $p<0.01$ at $15-$ 25th and 25-30th minutes for Disc1-L100 ${ }^{+1-}$ animals, respectively) (Fig. 3C,D).

\section{Social affiliation/recognition}

MANOVA found a main effect of MIA $\left(F_{(1,44)}=8.2 ; p<0.01\right)$, effect of the stranger $1\left(F_{(1,44)}=142.9 ; p<0.001\right)$, MIA $\times$ genotype $\left(F_{(1,44)}=7.1 ; p \leq 0.01\right)$, and MIA $\times$ stranger 1 $\left(F_{(1,44)}=10.6 ; p<0.01\right)$ interactions on social affiliation. As can be seen in Figure $3 E, \mathrm{PBS} /$ Disc1-L100 $\mathrm{P}^{+/-}$offspring explored the empty cylinder more $(p<0.01)$ and the cup containing stranger $1(p=0.072)$ in comparison with PBS/WT mice. PolyI:C given at $2.5 \mathrm{mg} / \mathrm{kg}$ did not affect social behavior in WT offspring. However polyI:C-2.5/Disc1-L100 ${ }^{+/-}$mice showed lack of social interest to stranger 1 , spending equal amounts of time on both sides of the social chamber. There was no effect of MIA, genotype, or their interactions on social recognition (all $p$ s $>0.05$ ); however, MANOVA detected a significant effect of stranger $2\left(F_{(1,44)}=188.8 ; p<0.001\right)$. Indeed, mice of all experimental groups spent significantly more time near stranger 2 than familiar stranger 1 (Fig. $3 F$ ).

\section{PPI}

Based on the PPI findings from Experiment 2, we assessed PPI in mice at 16 weeks of age. MANOVA found a main effect of MIA $\left(F_{(1,48)}=5.3 ; p<0.05\right)$, prepulse $\left(F_{(2,96)}=86.4 ; p<\right.$ $0.001)$, genotype $\times \operatorname{MIA}\left(F_{(1,48)}=4.7 ; p<0.05\right)$, and MIA $\times$ prepulse $\left(F_{(2,96)}=5.4 ; p<0.01\right)$ interactions. PolyI:C given at $2.5 \mathrm{mg} / \mathrm{kg}$ did not alter PPI in WT offspring, whereas PolyI:C2.5/Disc1-L100 ${ }^{+/-}$animals showed PPI deficits at all three prepulses in comparison with $\mathrm{PBS} /$ Disc1-L100P ${ }^{+/-}$mice $(p<$ 0.01 at $69 \mathrm{~dB}$; ps $<0.05$ at 73 and $81 \mathrm{~dB}$, respectively) (Fig. $4 A$ ). MANOVA also found an effect of genotype $\left(F_{(1,48)}=10.7 ; p<\right.$ 0.01 ) on startle response (Fig. $4 B$ ), but no effect of MIA or their interactions.

\section{Object recognition}

There was an effect of time intervals during the habituation session $\left(F_{(2,70)}=76.5 ; p<0.001\right)$ without any effects of MIA, genotype, or their interactions (Fig. 4C). MANOVA found a main effect of MIA $\left(F_{(1,35)}=8.8 ; p<0.01\right)$, DO $\left(F_{(1,35)}=\right.$ $109.4 ; p<0.001)$, MIA $\times$ genotype $\left(F_{(1,35)}=12.8 ; p \leq 0.01\right)$, and MIA $\times \operatorname{DO}\left(F_{(1,35)}=7.2, p<0.05\right)$ interactions. Control mice of both genotype distinguished spatial rearrangements and spent more time near DO than NDO (both $p s<0.01$ ), whereas PolyI:C-2.5/Disc1-L100 ${ }^{+/-}$offspring showed impaired spatial object recognition. Post hoc analysis revealed that PolyI:C-2.5/Disc1-L100 ${ }^{+/-}$offspring had less exploration of the DO $(p<0.01)$ in comparison with PBS/Disc1$\mathrm{L} 100 \mathrm{P}^{+/-}$mice, and as a result spent equal amounts of time near both types of objects (Fig. 4D). MANOVA found significant effect of $\mathrm{NO}\left(F_{(1,35)}=107.3 ; p<0.001\right)$ and genotype $\times$ NO interactions $\left(F_{(1,35)}=11.4 ; p<0.05\right)$. Mice of all experimental groups preferred to explore NO rather than FO (Fig. $4 E)$. There was no difference in time spent near the NO between PBS/WT and PBS/Disc1-L100 $\mathrm{P}^{+/-}$animals $(p>0.05)$, 

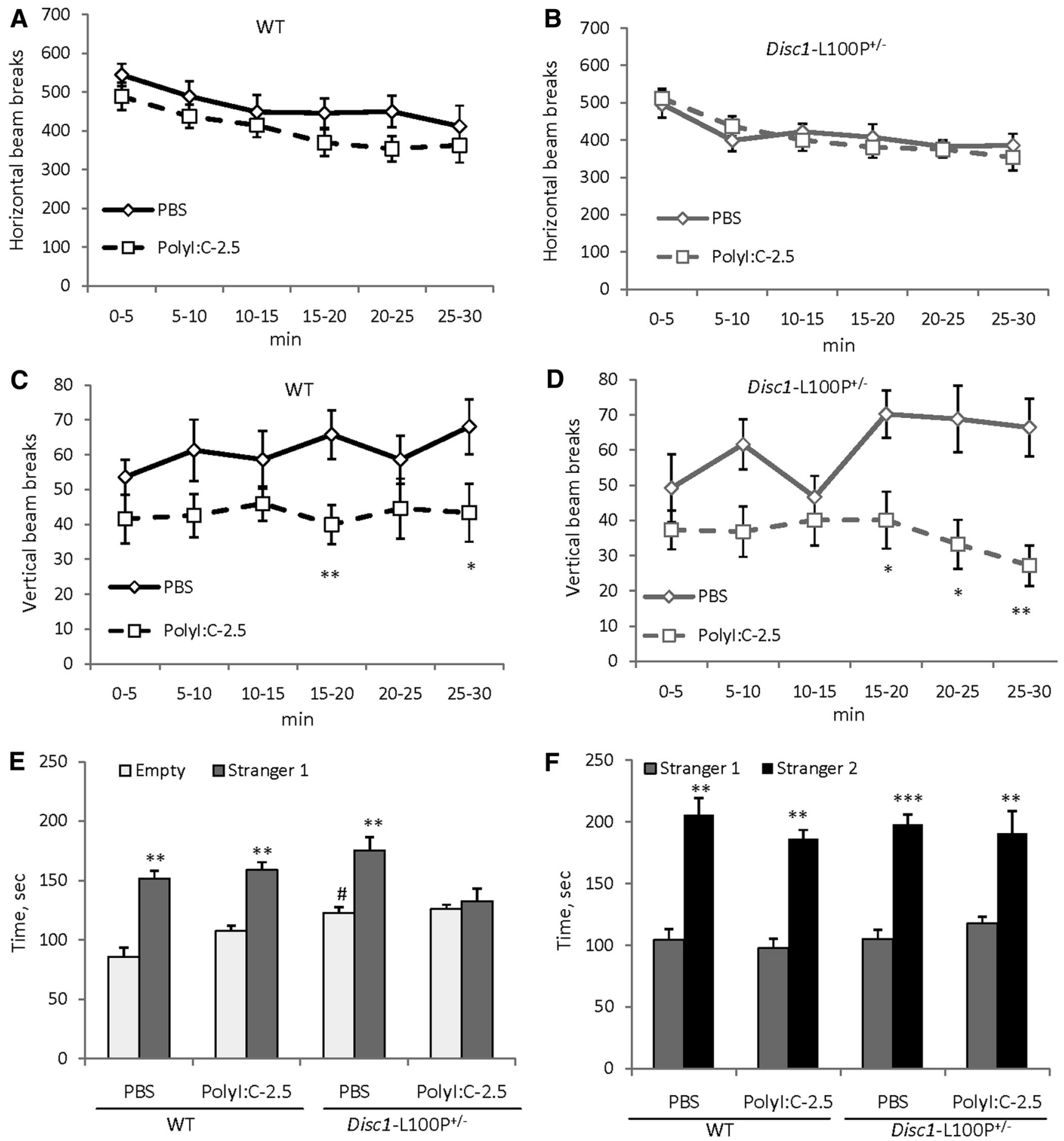

Figure 3. The effects of prenatal immune activation by $2.5 \mathrm{mg} / \mathrm{kg}$ of polyl:C on horizontal $(\boldsymbol{A}, \boldsymbol{B})$ and vertical activity $(\boldsymbol{C}, \boldsymbol{D})$, social affiliation $(\boldsymbol{E})$, and social recognition $(\boldsymbol{F})$ in WT and Disc1-L100P ${ }^{+/-}$mice. Adult mice of both genotypes born to polyl:C-treated mothers showed significantly reduced vertical activity in the 0 F $(\boldsymbol{C}, \boldsymbol{D})$, with no difference in horizontal activity $(\boldsymbol{A}, \boldsymbol{B})$ $\left(N=6-14\right.$ per each group). ${ }^{*} p<0.05 ;{ }^{* *} p<0.01$, in comparison with control (offspring born to PBS-treated mothers) within each genotype.E, Mean time spent near empty cylinder or unfamiliar mouse (stranger 1). MIA abolished social motivation specifically in Disc1-L100P ${ }^{+/-}$offspring but not in WT mice. $F$, Mice of all experimental groups showed intact social memory as they spent more time with a new, unfamiliar mouse (stranger 2 ). ${ }^{* *} p<0.01 ;{ }^{* * *} p<0.001$, in comparison with time spent near the empty cylinder $(\boldsymbol{E})$ or stranger $1(\boldsymbol{F})$ within each experimental group; ${ }^{\#} p<0.01$, in comparison with PBS/WT mice. $N=8-12$ per each group.

whereas PolyI:C-2.5/Disc1-L100P ${ }^{+/-}$offspring spent slightly less time with the $\mathrm{NO}$ in comparison with PBS/Disc1L100 $\mathrm{P}^{+/-}$mice $(p \leq 0.05)$.

LI

Mice of all experimental groups did not differ in A period ( $p s>$ 0.05 ; overall A period $=7.3 \mathrm{~s}$ ). MANOVA detected a main effect of pre-exposure $\left(F_{(1,58)}=5.0 ; p<0.05\right)$, genotype $\left(F_{(1,58)}=13.8\right.$; $p<0.001)$, and MIA $\times$ genotype $\left(F_{(1,58)}=14.2 ; p<0.001\right)$ interactions. PBS/WT mice expressed LI $(p<0.001)$, whereas Poly-2.5/WT offspring showed impaired LI ( $p>0.05$ ) (Fig. $4 F)$. PBS/Disc1-L100P ${ }^{+/-}$as well as Poly-2.5/Disc1-L100P ${ }^{+/-}$mice showed deficient LI (both $p$ s $>0.05$ ). 

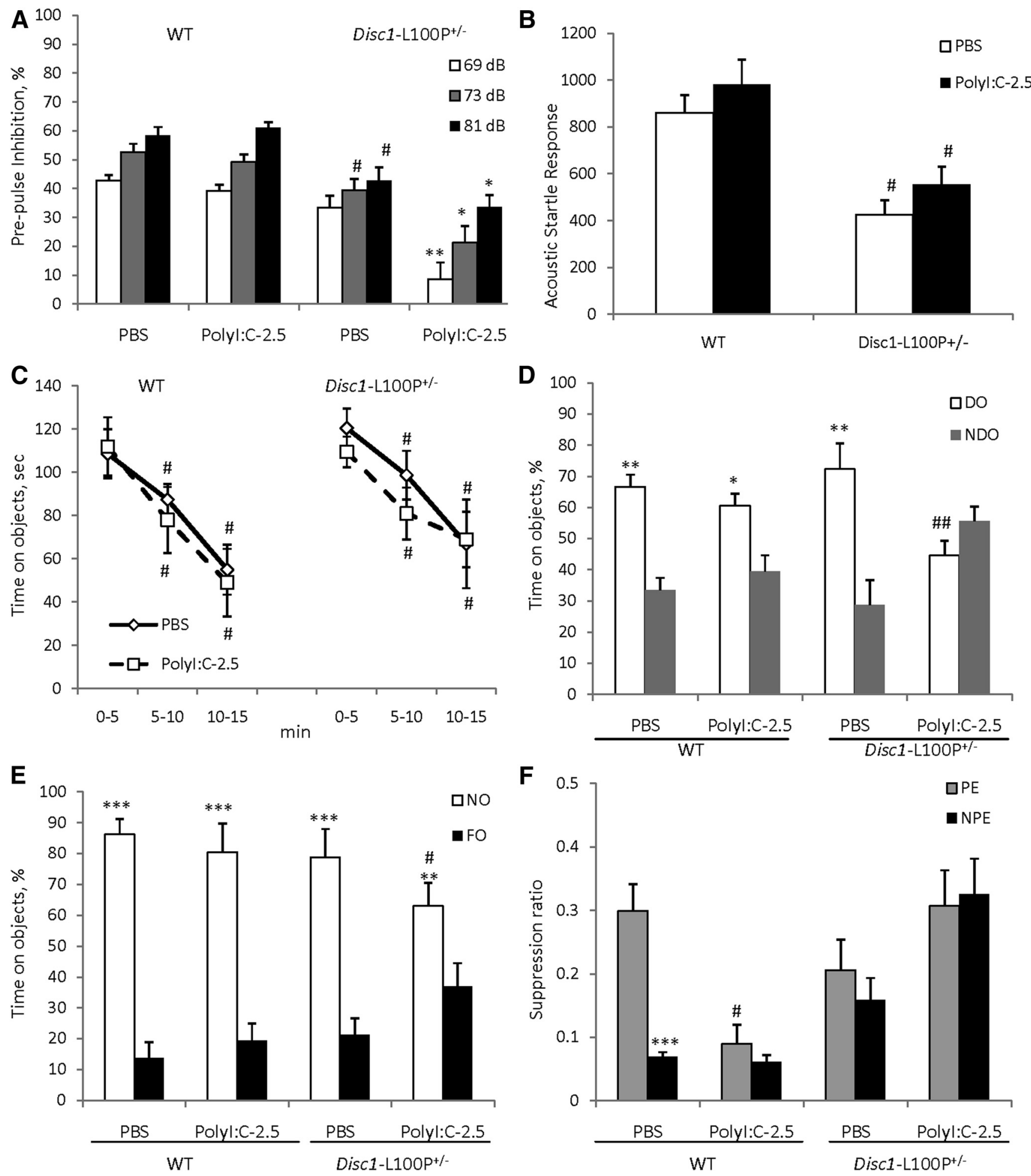

Figure 4. The effects of prenatal immune activation by $2.5 \mathrm{mg} / \mathrm{kg}$ of polyl:C on PPI $(\boldsymbol{A}), \mathrm{ASR}(\boldsymbol{B})$, object recognition $(\boldsymbol{C}-\boldsymbol{E})$, and LI $(\boldsymbol{F})$ in WT and Disc1-L100P ${ }^{+/-}$mice. $\boldsymbol{A}, 0$ nly DISC1-L100P ${ }^{+/-}$offspring born to mothers injected with $2.5 \mathrm{mg} / \mathrm{kg}$ of polyl:C showed a PPI deficit, with no effect on MIA on the startle response $(\boldsymbol{B})(\mathrm{N}=7-16$ per each group). Mice of all experimental groups showed comparable

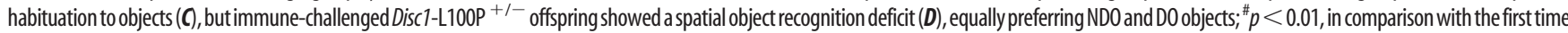
interval during habituation within each experimental group. Mice of all experimental groups showed comparable novel object recognition $(\boldsymbol{E}) . N=8-11$ per group; ${ }^{*} p<0.05 ;{ }^{* * *} p<0.01$; ${ }^{* * *} p<0.001$, compared with the time spent on either NDO or F0 within each experimental group; ${ }^{*} p \leq 0.05 ;{ }^{* \#} p<0.01$, in comparison with PBS/Disc1-L100P ${ }^{+/-}$mice. F, MIA with $2.5 \mathrm{mg} / \mathrm{kg}$ of polyl:C disrupted Ll in both WT and Disc $1-\mathrm{L} 100 \mathrm{P}^{+/-}$offspring. Mean suppression ratios of the PE and NPE mice conditioned with two conditioned stimulus - unconditioned stimulus trials and given 40 pre-exposures $(N=6-12$ per each group). ${ }^{* * *} p<0.001$, in comparison with PE within PBS-WT experimental group; ${ }^{*} p<0.05$, in comparison with PE PBS-WT control mice. 
Table 3. The effect of MIA on IL-6 in WT, Disc1-Q31L ${ }^{+/-}$, and Disc1-L100P $+/-$ fetal brains

\begin{tabular}{|c|c|c|c|}
\hline $\begin{array}{l}\text { Experimental } \\
\text { group }\end{array}$ & $\begin{array}{l}\mathrm{PBS}, \mathrm{pg} / \mu \mathrm{g} \\
\text { protein }\end{array}$ & $\begin{array}{l}\text { Polyl:C-2.5 mg/kg, } \\
\mathrm{pg} / \mu \mathrm{g} \text { protein }\end{array}$ & $\begin{array}{l}\text { Polyl:C-5.0 mg/kg, } \\
\mathrm{pg} / \mu \mathrm{g} \text { protein }\end{array}$ \\
\hline & $22.5 \pm 11.5$ & $86.8 \pm 25.4^{*}$ & $168.6 \pm 17.7^{* * *}$ \\
\hline Disc1-Q31L $\mathrm{L}^{+/-}$ & $21.1 \pm 5.9$ & $93.6 \pm 27.1^{*}$ & $212.1 \pm 25.9^{* * *}$ \\
\hline Disc1-L100P $+/-$ & $20.5 \pm 6.8$ & $315.7 \pm 31.5^{* * *}$ & $923.5 \pm 30.6^{* * *}$ \\
\hline
\end{tabular}

${ }^{*} p<0.05 ;{ }^{* * *} p<0.001$,-in comparison with control (fetuses of PBS-treated females) within each genotype. $N=$ 8 mice per each group.

\section{Experiment 3}

Increased IL-6 in Disc1-L100P ${ }^{+/-}$fetal brains in response to polyI:C

MANOVA found a main effect of genotype $\left(F_{(2,63)}=189.7 ; p<\right.$ $0.001)$, MIA $\left(F_{(2,63)}=434.0 ; p<0.001\right)$, and their interactions $\left(F_{(4,63)}=197.2 ; p<0.001\right)$ on fetal brain levels of IL-6. PolyI:C increased IL-6 in mice of all genotypes in a dose-dependent manner. However, Disc1-L100P ${ }^{+/-}$fetuses showed higher sensitivity to the lower dose of polyI:C, with much higher IL-6 levels $(p<$ $0.001)$ in comparison with WT $(p<0.01)$ or Disc1-Q31L $\mathrm{L}^{+/-}$ $(p<0.05)$ mice (Table 3$)$.

\section{The rescue effect of anti-IL-6 on polyI:C-induced behavioral abnormalities in Disc1-L100P ${ }^{+/-}$offspring \\ PPI}

MANOVA detected a main effect of prepulse $\left(F_{(2,78)}=18.4 ; p<\right.$ $0.001)$, genotype $\left(F_{(1,39)}=15.0 ; p<0.001\right)$, MIA + anti-IL-6 $\left(F_{(2,39)}=4.3 ; p<0.05\right)$, and genotype $\times$ MIA + anti-IL-6 interactions $\left(F_{(2,39)}=5.5, p<0.01\right)$. Disc1-L100P $\mathrm{P}^{+/-}$offspring of polyI:C-treated dams had worse PPI deficits compared with PBS/ Disc1-L100P ${ }^{+/-}$mice at all three prepulses ( $p$ s $<0.01$ at 69,73 , and $p<0.05$, at $81 \mathrm{~dB}$ ). Coadministration of anti-IL-6 with polyI:C reversed the impaired PPI in Disc1-L100P ${ }^{+/-}$offspring $(p<0.001$ at $69 \mathrm{~dB}, p<0.01$ at $73 \mathrm{~dB}$, and $p<0.05$ at $81 \mathrm{~dB}$ in comparison with poly-2.5/Disc1-L100 $\mathrm{P}^{+/-}$mice) (Fig. 5A). MANOVA also found a main effect of genotype $\left(F_{(1,39)}=4.5 ; p<\right.$ $0.05)$ and genotype $\times$ MIA + anti-IL-6 interaction $\left(F_{(2,39)}=5.9\right.$, $p<0.01$ ) on ASR (Fig. 5B). Anti-IL-6 + Poly-2.5/Disc1L100 $\mathrm{P}^{+/-}$mice had modestly increased ASR $(p=0.08)$.

\section{$L I$}

Mice of all experimental groups did not differ in the A period ( $p s>0.05$; overall A period $=8.1 \mathrm{~s})$. MANOVA found a significant effect of pre-exposure $\left(F_{(1,86)}=30.3 ; p<0.001\right)$, genotype $\left(F_{(1,86)}=13.1 ; p<0.001\right)$, genotype $\times$ MIA + anti-IL-6 $\left(F_{(2,86)}=10.1 ; p<0.001\right)$, and pre-exposure $\times$ MIA + anti-IL$6\left(F_{(2,86)}=8.2 ; p<0.001\right)$ interactions. PBS/WT mice expressed LI as expected ( $p<0.001)$, whereas Poly-2.5/WT and Poly-2.5/ Disc1-L100P ${ }^{+/-}$showed impaired LI, which was rescued by coadministration of anti-IL- 6 with polyI:C $(p<0.001$ and $p<0.01$, respectively) (Fig. 5C).

\section{Discussion}

In this study we demonstrated that the behavioral effects of MIA can be modified by Discl gene polymorphisms in a mouse model. The Disc1-L100P ${ }^{-1-}$ mutation produces schizophrenia-related behavioral, cellular, and biochemical phenotypes (Clapcote et al., 2007; Lipina et al., 2010, 2011, 2012; Lee et al., 2011), while the Disc1-Q31L ${ }^{-1-}$ mutation results in a phenotype related to depression (Clapcote et al., 2007; Haque et al., 2012; Lipina et al., 2013a). We found that polyI:C had a greater effect on maternal immune response and abnormal behavior in Disc1-L100 ${ }^{+/-}$ mutants compared with WT or Disc1-Q31L ${ }^{+/-}$mice. This is significant because maternal infection in humans is a strong risk factor for schizophrenia but not depression. In particular, MIA by polyI:C at low doses aggravates PPI and LI deficits, and reduces social motivation and spatial object recognition in Disc1L100P ${ }^{+/-}$offspring but not in WT. IL-6 release is higher in Disc1-L100P ${ }^{+/-}$fetuses than WT or Disc1-Q31L ${ }^{+/-}$after polyI:C exposure. The effects of polyI:C on later PPI and LI could be blocked by anti-IL-6 antibody coinjected with polyI:C in Disc1L100P $\mathrm{P}^{+/-}$offspring, further supporting the crucial role of IL- 6 in the mechanisms of MIA-induced neurodevelopmental abnormalities (Smith et al., 2007).

Strikingly, MIA with $5 \mathrm{mg} / \mathrm{kg}$ of polyI:C inDisc1-L100P $\mathrm{P}^{+/-}$ dams resulted in no offspring. The same dose of polyI:C had no effect on the number of offspring born to WT and Disc1$\mathrm{Q}_{31 \mathrm{~L}^{+/-}}$females. No miscarriage or aborted fetuses were detected in the Disc1-L100P ${ }^{+/-}$dams given $5 \mathrm{mg} / \mathrm{kg}$ of polyI:C. A limitation of the present study is that we used Disc1-Q31L $\mathrm{L}^{+/-}$ and Disc1-L100P ${ }^{+/-}$dams, mated with WT males, but not WT females mated with Discl mutant male mice. Thus, the MIA could interact with maternal genotype, in addition to fetal genotype, to affect the outcome in adult offspring. As an animal model for the interaction between genetic susceptibility and maternal infection in schizophrenia, both mating approaches would be informative, since both parents may carry genetic variants predisposing to schizophrenia.

The increased level of IL- 6 detected in Disc1-L100P ${ }^{+/-}$fetuses in response to polyI:C, especially at $5 \mathrm{mg} / \mathrm{kg}$, likely reflects a more pronounced maternal inflammatory response in Disc1-L100 ${ }^{+/-}$ dams that could explain the lack of live pups in this group. There is evidence that elevated IL- 6 is involved in infertility, recurrent miscarriage, pre-eclampsia, and preterm delivery (Prins et al., 2012). Possible mechanisms include inhibition of CD4+ T regulatory cell production by elevated IL-6 (Bettelli et al., 2006), which affects immune tolerance of pregnancy. Termination of pregnancy by immune mechanisms has been reported in humans (Salmon, 2004), further supporting our observations.

In contrast, the effects of MIA on Disc1-Q31L ${ }^{+/-}$mice were similar to WT mice, indicating the lack of interaction between MIA and Disc1-Q31L genotype. Both WT and Disc1-Q31L ${ }^{+/-}$ mice born to polyI:C-treated mothers had deficits in exploratory behavior and mild hyperactivity, consistent with previous reports (Shi et al., 2003; Meyer et al., 2005; Smith et al., 2007; Abazyan et al., 2010; Ibi et al., 2010; Vuillermot et al., 2012). The same decrease of rearing behavior was detected in WT and Disc1L100P ${ }^{+/-}$offspring born to mothers treated with $2.5 \mathrm{mg} / \mathrm{kg}$ of polyI:C. Such reduced exploratory activity could be attributed to higher anxiety as suggested (Shi et al., 2003). Indeed, Disc1Q31L ${ }^{+/-}$offspring showed behaviors consistent with increased anxiety in the EPM. However, MIA had no effect on EPM behavior in WT and Disc1-L100P ${ }^{+/-}$(data not shown), which is in agreement with other studies (Meyer et al., 2005; Abazyan et al., 2010).

Because the Disc1-Q31L mutation causes depression-like behavioral changes, we used the FST, which is commonly used to screen antidepressant medication effects (Cryan and Holmes, 2005). Heterozygous Disc1-Q31L ${ }^{+/-}$mice do not have an abnormal FST (Clapcote et al., 2007), but we sought to test whether the additional insult of exposure to prenatal maternal inflammation would affect the FST. We did not see an interaction between MIA and the Disc1-Q31L ${ }^{+/-}$, which is congruent with the lack of association between maternal infection in humans and depression in the offspring (Pang et al., 2009). Similar behavioral effects were seen in polyI:C-treated mothers of WT and Disc1-Q31L ${ }^{+/-}$off- 

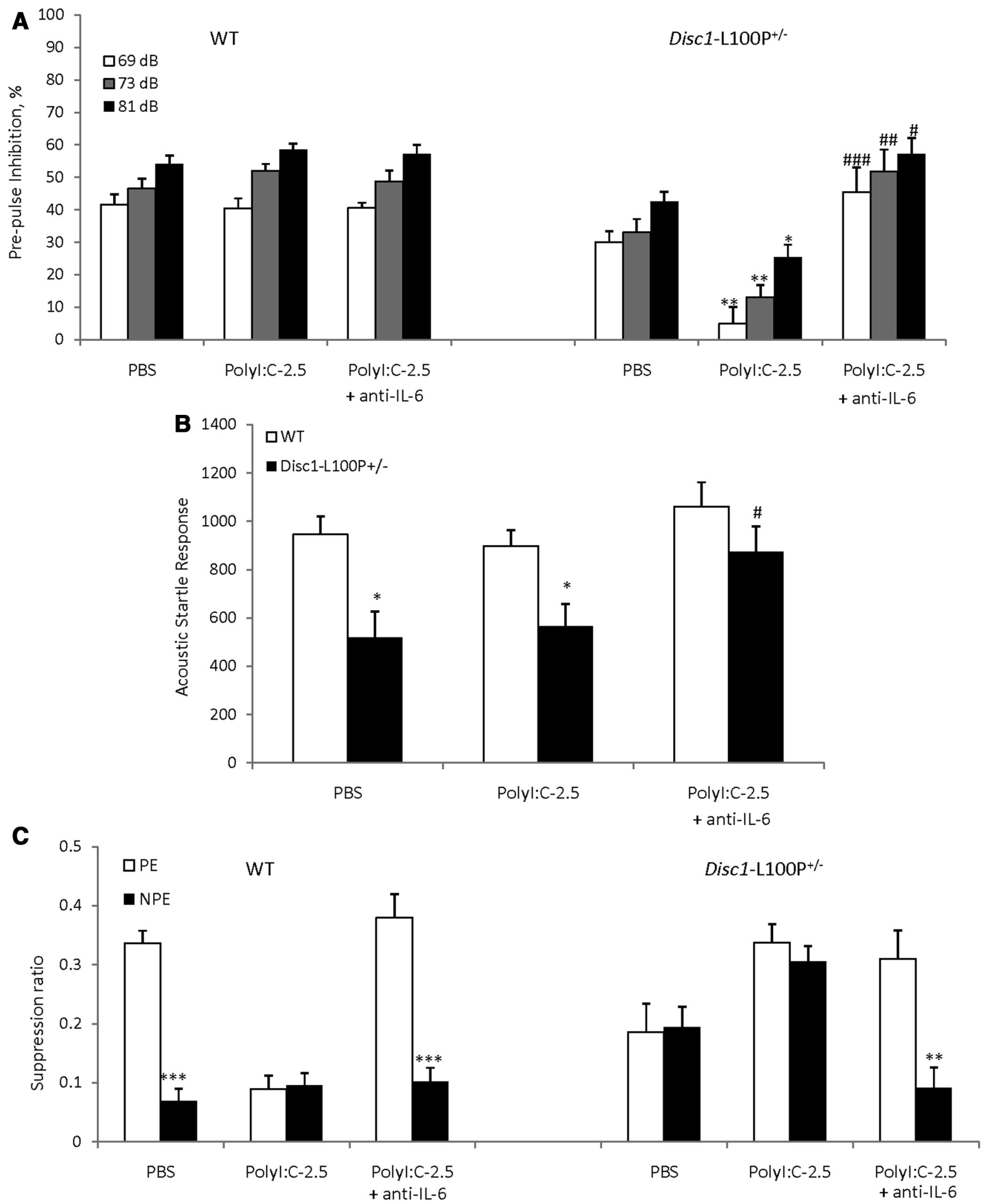

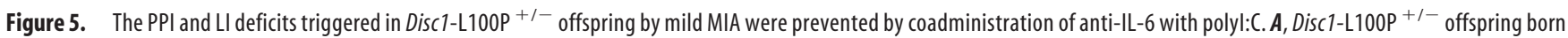
to mothers injected with $2.5 \mathrm{mg} / \mathrm{kg}$ of polyl:C had a PPI deficit. Coadministration of anti-IL- 6 with polyl:C blocked PPl impairment, with a mild increase of startle response $(\boldsymbol{B}){ }^{*} p<0.05$; ${ }^{* *} p<0.01$, in comparison with Disc1-L100P ${ }^{+/-}$offspring born to PBS-treated females. $N=8-9$ per group (C). Mean suppression ratios of the PE and NPE mice conditioned with two conditioned stimulus - unconditioned stimulus trials and given 40 pre-exposures $\left(N=6-9\right.$ per each group). ${ }^{* *} p<0.01 ;{ }^{* * *} p<0.001$, in comparison with $\mathrm{PE}$ within each experimental group. 
spring on PPI, spatial object recognition, and LI, which is consistent with previous reports of MIA effects on schizophrenia- and autism-related behavioral phenotypes (Patterson, 2009) and disruptions in brain dopamine, GABA, and glutamate systems (Zuckerman et al., 2003; Meyer and Feldon, 2009; Vuillermot et al., 2010).

In addition to the main finding that MIA affected Disc1-

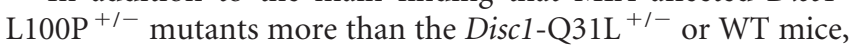
we found that the effect of polyI:C on PPI was age and dose dependent. PolyI:C given at $5 \mathrm{mg} / \mathrm{kg}$ but not at $2.5 \mathrm{mg} / \mathrm{kg}$ to pregnant females induced PPI deficits in WT offspring, confirming previous reports (Meyer et al., 2005; Vuillermot et al., 2012). Importantly, sensorimotor gating was impaired at 16 weeks of age mice, but not at 8 weeks of age, supporting the importance of development of the effects of polyI:C (Meyer and Feldon, 2012). The delayed onset of MIA effects could be useful in testing potential early interventions to prevent schizophrenia ( $\mathrm{Li}$ et al., 2010; Piontkewitz et al., 2011, 2012), which is a major clinical priority (Insel, 2010). We recently reported that the emergence of abnormal behaviors in Disc1-L100P ${ }^{-1-}$ mutants could be prevented by valproic acid (Lipina et al., 2012). PolyI:C at both studied doses disrupted LI in WT offspring, supporting previous reports on C57BL/6 mice (Meyer et al., 2005; Smith et al., 2007). The LI paradigm is based on the phenomenon of reduced conditioning after stimulus pre-exposure and measures the ability to ignore irrelevant stimuli. LI is disrupted in acute episodes of schizophrenia (Gray et al., 1992) and by amphetamine in rodents (Weiner et al., 1988; Lipina et al., 2010).

Given the prominent role of dopamine in psychopathology of schizophrenia, a wide range of studies has shown that prenatal immune activation increases tyrosine hydroxylase (Borrell et al., 2002), elevates dopamine and its metabolite levels in the nucleus accumbens of rats (Romero et al., 2007) and mice (Meyer et al., 2008), and increases striatal dopamine with reduced binding of D2 receptors (Ozawa et al., 2006). Such imbalance in the mesolimbic dopamine systems may explain disrupted LI and other schizophrenia-related behavioral phenotypes due to polyI:C exposure (Meyer and Feldon, 2009). Notably, MIA in Disc1-

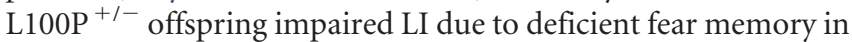
NPE animals. A similar impairment of contextual fear memory was also observed in DN-DISC1 mutant offspring born to polyI: C-treated dams, which correlated with increased $\mathrm{BrdU}^{+}$cells in the granule cell layer of the hippocampus (Ibi et al., 2010). Thus, impaired hippocampal function might partially explain the deficient $\mathrm{LI}$ in MIA $\times$ Discl-L100P ${ }^{+/-}$mice.

Indeed, immune-challenged Disc1-L100P ${ }^{+/-}$offspring also demonstrated spatial object recognition deficits, which relies on intact hippocampal function (Roullet et al., 2001). In contrast to the findings of Ibi et al. (2010) and Ito et al. (2010), novel object recognition was not affected by either Disc1 mutation or MIA in our experiments. A small reduction of novel object exploration was detected in Poly-2.5/Disc1-L100P $\mathrm{P}^{+/-}$animals (Fig. 4). This discrepancy might be due to differences between the transgenic dominant-negative Disc1 mouse and our point mutant Disc1 mouse. There were also differences in the behavioral protocols. Our procedure assessed spatial and novel object recognition on the same day, after a short time interval, whereas Ibi et al. (2010) tested only novel object recognition after an interval of $1 \mathrm{~h}$. Ito et al (2010) employed a protocol without standard habituation to objects and used different time intervals to assess spatial object location $(24 \mathrm{~h}$ ) and novel object recognition (5 $\mathrm{min})$.

Social dysfunction is an important component of schizophrenia, so we assessed social interest and recognition in our mouse model. The social affiliation test measures preference for another mouse over an empty chamber, while the social recognition test assesses preference for a novel versus familiar mouse. The affiliation session estimates social motivation, whereas the recognition session reflects social memory and capacity to discriminate a socially novel stimulus (Brodkin et al., 2004; O'Tuathaigh et al., 2007). We found a specific deficit in social motivation, rather than social recognition in Poly-2.5/Disc1-L100P ${ }^{+/-}$mice, which correlates with their intact novel object recognition. Another genetic mutant mouse model for schizophrenia, Grin $1^{\mathrm{D} 481 \mathrm{~N}}$, also shows a similar behavioral profile in these two tasks (Labrie et al., 2008).

The main finding is that MIA interacts with the Disc1-L100P mutation that causes abnormalities related to schizophrenia, with no interaction with the Disc1-Q31L mutation. Thus, our results indicate that a specific combination of genetic and environmental factors can disrupt brain development to cause behavioral abnormalities. Similar gene $\times$ environment interactions have been reported in other mutants, including DN-DISC1 (Ibi et al., 2010), hmDISC1 (Abazyan et al., 2010), Nurr1 ${ }^{+/-}$ (Vuillermot et al., 2012), and Tsc2 ${ }^{+/-}$(Ehninger et al., 2012). Given that schizophrenia is associated with multiple genes, the polyI:C approach could be used to model the effects of maternal infection on many genetic risk factors.

IL-6 appears to be crucial for mediating the effects of MIA on fetal brain development. We found that polyI:C led to a marked increase in IL-6 in a dose- and genotype-dependent manner with a comparable basal level between the genotypes. Most notably, we found that Disc1-L100P ${ }^{+/-}$fetuses showed much higher IL-6 levels after MIA with polyI:C at $2.5 \mathrm{mg} / \mathrm{kg}$ than WT and Disc1Q31 $\mathrm{L}^{+/-}$mice. Anti-IL-6 antibodies were effective in preventing the adverse effects of polyI:C exposure, confirming the importance of IL-6 in the pathophysiology of MIA. A recent study (Garbett et al., 2012) detected overexpression of the crystalline gene family in the embryonic brain induced by three different types of MIA: influenza virus, polyI:C, and IL-6, suggesting a common cascade of events induced by these environmental insults.

How the Disc1-L100P mutation interacts with MIA is not clear, given the complexity of DISC1 interactome (Camargo et al., 2007). However, it is possible to speculate about potential mechanisms. First of all, the Disc1-L100P mutation increases GSK-3 activity (Lipina et al., 2011), which is a key regulator of the inflammatory response (Wang et al., 2011). Increased GSK-3 activity was also detected in immune-challenged hmDISC1 newborn offspring (Abazyan et al., 2010). Hence, the increased GSK-3 activity induced by Disc1-L100P mutation could alter the immune response, including IL-6 release, and in turn increase the reactivity of glial cells (Eskes et al., 2002). Our recent study showed that the Disc1-L100P mutation increased astroglial numbers near the subventricular zone of the brain via overexpression of $l c n 2$ (Lipina et al., 2012), a newly detected gliotransmitter (Lee et al., 2009). Moreover, immune stimulation by the endotoxin LPS increased the expression of $l c n 2$ in vitro (Lee et al., 2009), indicating the important role of $l c n 2$ in polyI:C-induced pathogenic mechanisms. Indeed, MIA in rodents (Borrell et al., 2002; Fatemi et al., 2002, 2004; Samuelsson et al., 2006) resulted in increased numbers and activation of astrocytes and microglia in the brain. Astrocytes and microglia are the main sources of cytokine production in the CNS (Benveniste, 1998), and glia are important in the formation of dopaminergic (Tai et al., 2007) and glutamatergic (Wolosker, 2011) systems. Future studies could explore the role of glial-neuronal interactions in 
response to immune activation and how this might affect early brain development.

In conclusion, the present study identified specific interactions between discrete genetic (Disc1-L100 ${ }^{+/-}$) and environmental (MIA) factors that exacerbate schizophrenia-related phenotypes with no interactions between Disc1-Q31L ${ }^{+/-}$and MIA to trigger depression-related phenotypes. Hence, the present MIA $\times$ Disc1-L100P ${ }^{+/-}$model may be a helpful tool for future studies to understand how prenatal infections can increase the risk for such brain disorders as schizophrenia.

\section{References}

Abazyan B, Nomura J, Kannan G, Ishizuka K, Tamashiro KL, Nucifora F, Pogorelov V, Ladenheim B, Yang C, Krasnova IN, Cadet JL, Pardo C, Mori S, Kamiya A, Vogel MW, Sawa A, Ross CA, Pletnikov MV (2010) Prenatal interaction of mutant DISC1 and immune activation produces adult psychopathology. Biol Psychiatry 68:1172-1181. CrossRef Medline

Benveniste EN (1998) Cytokine actions in the central nervous system. Cytokine Growth Factor Rev 9:259-275. CrossRef Medline

Bettelli E, Carrier Y, Gao W, Korn T, Strom TB, Oukka M, Weiner HL, Kuchroo VK (2006) Reciprocal developmental pathways for the generation of pathogenic effector TH17 and regulatory T cells. Nature 441:235238. CrossRef Medline

Borrell J, Vela JM, Arévalo-Martin A, Molina-Holgado E, Guaza C (2002) Prenatal immune challenge disrupts sensorimotor gating in adult rats. Implications for the etiopathogenesis of schizophrenia. Neuropsychopharmacology 26:204-215. CrossRef Medline

Brandon NJ, Sawa A (2011) Linking neurodevelopmental and synaptic theories of mental illness through DISC1. Nat Rev Neurosci 12:707-722. CrossRef Medline

Brodkin ES, Hagemann A, Nemetski SM, Silver LM (2004) Social approachavoidance behavior of inbred mouse strains towards DBA/2 mice. Brain Res 1002:151-157. CrossRef Medline

Brown AS, Derkits EJ (2010) Prenatal infection and schizophrenia: a review of epidemiologic and translational studies. Am J Psychiatry 167:261-280. CrossRef Medline

Camargo LM, Collura V, Rain JC, Mizuguchi K, Hermjakob H, Kerrien S, Bonnert TP, Whiting PJ, Brandon NJ (2007) Disrupted-inSchizophrenia-1 Interactome: evidence for the close connectivity of risk genes and a potential synaptic basis for schizophrenia. Mol Psychiatry 12:74-86. CrossRef Medline

Chubb JE, Bradshaw NJ, Soares DC, Porteous DJ, Millar JK (2008) The DISC locus in psychiatric illness. Mol Psychiatry 13:36-64. CrossRef Medline

Clapcote SJ, Lipina TV, Millar JK, Mackie S, Christie S, Ogawa F, Lerch JP, Trimble K, Uchiyama M, Sakuraba Y, Kaneda H, Shiroishi T, Houslay MD, Henkelman RM, Sled JG, Gondo Y, Porteous DJ, Roder JC (2007) Behavioral phenotypes of Discl missense mutations in mice. Neuron 54:387-402. CrossRef Medline

Clarke MC, Tanskanen A, Huttunen M, Whittaker JC, Cannon M (2009) Evidence for an interaction between familial liability and prenatal exposure to infection in the causation of schizophrenia. Am J Psychiatry 166: 1025-1030. CrossRef Medline

Cryan JF, Holmes A (2005) The ascent of mouse: advances in modelling human depression and anxiety. Nat Rev Drug Discov 4:775-790. CrossRef Medline

Ehninger D, Sano Y, de Vries PJ, Dies K, Franz D, Geschwind DH, Kaur M, Lee YS, Li W, Lowe JK, Nakagawa JA, Sahin M, Smith K, Whittemore V, Silva AJ (2012) Gestational immune activation and Tsc2 haploinsufficiency cooperate to disrupt fetal survival and may perturb social behavior in adult mice. Mol Psychiatry 17:62-70. CrossRef Medline

Eskes C, Honegger P, Juillerat-Jeanneret L, Monnet-Tschudi F (2002) Microglial reaction induced by noncytotoxicmethylmercury treatment leads to neuroprotection via interactions with astrocytes and IL-6 release. Glia 37:43-52. CrossRef Medline

Fatemi SH, Emamian ES, Sidwell RW, Kist DA, Stary JM, Earle JA, Thuras P (2002) Human influenza viral infection in utero alters glial fibrillary acidic protein immunoreactivity in the developing brains of neonatal mice. Mol Psychiatry 7:633-640. CrossRef Medline

Fatemi SH, Araghi-Niknam M, Laurence JA, Stary JM, Sidwell RW, Lee S (2004) Glial fibrillary acidic protein and glutamic acid decarboxylase 65 and $67 \mathrm{kDaproteinsare} \mathrm{increased} \mathrm{in} \mathrm{brains} \mathrm{of} \mathrm{neonatal} \mathrm{BALB} / \mathrm{c}$ mice following viral infection in utero. Schizophr Res 69:121-123. CrossRef Medline

Garbett KA, Hsiao EY, Kálmán S, Patterson PH, Mirnics K (2012) Effects of maternal immune activation on gene expression patterns in the fetal brain. Transl Psychiatry 2:e98. CrossRef Medline

Gray NS, Hemsley DR, Gray JA (1992) Abolition of latent inhibition in acute, but not chronic schizophrenics. Neurol Psychiatr Brain Res $1: 83-89$.

Haque FN, Lipina TV, Roder JC, Wong AH (2012) Social defeat interacts with Discl mutations in the mouse to affect behavior. Behav Brain Res 233:337-344. CrossRef Medline

Harrison PJ, Weinberger DR (2005) Schizophrenia genes, gene expression, and neuropathology: on the matter of their convergence. Mol Psychiatry 10:40-68; image 5. CrossRef Medline

Ibi D, Nagai T, Koike H, Kitahara Y, Mizoguchi H, Niwa M, Jaaro-Peled H, Nitta A, Yoneda Y, Nabeshima T, Sawa A, Yamada K (2010) Combined effect of neonatal immune activation and mutant DISC1 on phenotypic changes in adulthood. Behav Brain Res 206:32-37. CrossRef Medline

Insel TR (2010) Rethinking schizophrenia. Nature 468:187-193. CrossRef Medline

Ito HT, Smith SEP, Hsiao E, Patterson PH (2010) Maternal immune activation alters nonspatial information processing in the hippocampus of the adult offspring. Brain Behav Immun 24:930-941. CrossRef Medline

Jaaro-Peled H, Hayashi-Takagi A, Seshadri S, Kamiya A, Brandon NJ, Sawa A (2009) Neurodevelopmental mechanisms of schizophrenia: understanding disturbed postnatal brain maturation through neuregulin-1-ErbB4 and DISC1. Trends Neurosci 32:485-495. CrossRef Medline

Labrie V, Lipina T, Roder JC (2008) Mice with reduced NMDA receptor glycine affinity model some of the negative and cognitive symptoms of schizophrenia. Psychopharmacology 200:217-230. CrossRef Medline

Lee FH, Fadel MP, Preston-Maher K, Cordes SP, Clapcote SJ, Price DJ, Roder JC, Wong AH (2011) Discl point mutations in mice affect development of the cerebral cortex. J Neurosci 31:3197-3206. CrossRef Medline

Lee S, Park JY, Lee WH, Kim H, Park HC, Mori K, Suk K (2009) Lipocalin-2 is an autocrine mediator of reactive astrocytosis. J Neurosci 29:234-249. CrossRef Medline

Li Q, Cheung C, Wei R, Cheung V, Hui ES, You Y, Wong P, Chua SE, McAlonan GM, Wu EX (2010) Voxel-based analysis of postnatal white matter microstructure in mice exposed to immune challenge in early or late pregnancy. Neuroimage 52:1-8. CrossRef Medline

Lipina TV, Niwa M, Jaaro-Peled H, Fletcher PJ, Seeman P, Sawa A, Roder JC (2010) Enhanced dopamine function in DISC1-L100P mutant mice: implications for schizophrenia. Genes Brain Behav 9:777-789. CrossRef Medline

Lipina TV, Kaidanovich-Beilin O, Patel S, Wang M, Clapcote SJ, Liu F, Woodgett JR, Roder JC (2011) Genetic and pharmacological evidence for schizophrenia-related Disc1 interaction with GSK-3. Synapse 65:234248. CrossRef Medline

Lipina TV, Haque FN, McGirr A, Boutros PC, Berger T, Mak TW, Roder JC, Wong AH (2012) Prophylactic valproate acid treatment prevents schizophrenia-related behaviour in Disc1-L100P mutant mice. PLoS One 7:e51562. CrossRef Medline

Lipina TV, Fletcher PJ, Lee FH, Wong AH, Roder JC (2013a) Disrupted-InSchizophrenia-1 Gln31Leu polymorphism results in social anhedonia associated with monoaminergic imbalance and reduction of CREB and $\beta$-arrestin-1,2 in the nucleus accumbens in a mouse model of depression. Neuropsychopharmacology 38:423-436. CrossRef Medline

Lipina TV, Palomo V, Gil C, Martinez A, Roder JC (2013b) Dual inhibitor of PDE7 and GSK-3-VP1.15 acts as antipsychotic and cognitive enhancer in C57BL/6J mice. Neuropharmacology 64:205-214. CrossRef Medline

Longman RE, Johnson TR (2007) Viral respiratory disease in pregnancy. Curr Opin Obstet Gynecol 19:120-125. CrossRef Medline

Meyer U, Feldon J (2009) Neural basis of psychosis-related behaviour in the infection model of schizophrenia. Behav Brain Res 204:322-334. CrossRef Medline

Meyer U, Feldon J (2012) To poly(I:C) or not to poly(I:C): advancing preclinical schizophrenia research through the use of prenatal immune activation models. Neuropharmacology 62:1308-1321. CrossRef Medline

Meyer U, Feldon J, Schedlowski M, Yee BK (2005) Towards an immunoprecipitated neurodevelopmental animal model of schizophrenia. Neurosci Biobehav Rev 29:913-947. CrossRef Medline 
Meyer U, Nyffeler M, Schwendener S, Knuesel I, Yee BK, Feldon J (2008) Relative prenatal and postnatal maternal contributions to schizophreniarelated neurochemical dysfunction after in utero immune challenge. Neuropsychopharmacology 33:441-456. CrossRef Medline

Nagai T, Kitahara Y, Ibi D, Nabeshima T, Sawa A, Yamada K (2011) Effects of antipsychotics on the behavioral deficits in human dominant-negative DISC1 transgenic mice with neonatal polyI:Ctreatment. Behav Brain Res 225:305-310. CrossRef Medline

O’Tuathaigh CM, Babovic D, O'Sullivan GJ, Clifford JJ, Tighe O, Croke DT, Harvey R, Waddington JL (2007) Phenotypic characterization of spatial cognition and social behavior in mice with 'knockout' of the schizophrenia risk gene neuregulin 1. Neuroscience 147:18-27. CrossRef Medline

Ozawa K, Hashimoto K, Kishimoto T, Shimizu E, Ishikura H, Iyo M (2006) Immune activation during pregnancy in mice leads to dopaminergic hyperfunction and cognitive impairment in the offspring: a neurodevelopmental animal model of schizophrenia. Biol Psychiatry 59:546-554. CrossRef Medline

Pang D, Syed S, Fine P, Jones PB (2009) No association between prenatal viral infection and depression in later life - a long-term cohort study of 6152 subjects. Can J Psychiatry 54:565-570. Medline

Patterson PH (2009) Immune involvement in schizophrenia and autism: etiology, pathology, and animal models. Behav Brain Res 204:313-321. CrossRef Medline

Piontkewitz Y, Arad M, Weiner I (2011) Abnormal trajectories of neurodevelopment and behavior following in utero insult in the rat. Biol Psychiatry 70:842-851. CrossRef Medline

Piontkewitz Y, Arad M, Weiner I (2012) Tracing the development of psychosis and its prevention: what can be learned from animal models. Neuropharmacology 62:1273-1289. CrossRef Medline

Prins JR, Gomez-Lopez N, Robertson SA (2012) Interleukin-6 in pregnancy and gestational disorders. J Reprod Immunol 95:1-14. CrossRef Medline

Riley B, Kendler KS (2006) Molecular genetic studies of schizophrenia. Eur J Hum Genet 14:669-680. CrossRef Medline

Romero E, Ali C, Molina-Holgado E, Castellano B, Guaza C, Borrell J (2007) Neurobehavioral and immunological consequences of prenatal immune activationin rats. Influence of antipsychotics. Neuropsychopharmacology 32:1791-1804. CrossRef Medline

Roullet P, Sargolini F, Oliverio A, Mele A (2001) NMDA and AMPA antagonist infusions into the ventral striatum impair different steps of spatial information processing in a nonassociative task in mice. J Neurosci 21: 2143-2149. Medline
Salmon JE (2004) A noninflammatory pathway for pregnancy loss: innate immune activation? J Clin Invest 114:15-17. CrossRef Medline

Samuelsson AM, Jennische E, Hansson HA, Holmäng A (2006) Prenatal exposure to interleukin-6 results in inflammatory neurodegeneration in hippocampus with NMDA/GABA(A) dysregulation and impaired spatial learning. Am J Physiol Regul Integr Comp Physiol 290:R1345-R1356. Medline

Selten JP, Frissen A, Lensvelt-Mulders G, Morgan VA (2010) Schizophrenia and 1957 pandemic of influenza: meta-analysis. Schizophr Bull 36:219-228. CrossRef Medline

Shi L, Fatemi SH, Sidwell RW, Patterson PH (2003) Maternal influenza infection causes marked behavioural and pharmacological changes in the offspring. J Neurosci 23:297-302. Medline

Smith SE, Li J, Garbett K, Mirnics K, Patterson PH (2007) Maternal immune activation alters fetal brain development through interleukin-6. J Neurosci 27:10695-10702. CrossRef Medline

Tai YF, Pavese N, Gerhard A, Tabrizi SJ, Barker RA, Brooks DJ, Piccini P (2007) Imaging microglial activation in Huntington's disease. Brain Res Bull 72:148-151. CrossRef Medline

Vuillermot S, Weber L, Feldon J, Meyer U (2010) A longitudinal examination of the neurodevelopmental impact of prenatal immune activation in mice reveals primary defects in dopaminergic development relevant to schizophrenia. J Neurosci 30:1270-1287. CrossRef Medline

Vuillermot S, Joodmardi E, Perlmann T, Ögren SO, Feldon J, Meyer U (2012) Prenatal immune activation interacts with genetic Nurrl deficiency in the development of attentional impairments. J Neurosci 32: 436-451. CrossRef Medline

Wang H, Brown J, Martin M (2011) Glycogen synthase kinase 3: a point of convergence for the host inflammatory response. Cytokine 53:130-140. CrossRef Medline

Weiner I, Lubow RE, Feldon J (1988) Disruption of latent inhibition by acute administration of low doses of amphetamine. Pharmacol Biochem Behav 30:871-878. CrossRef Medline

Wolosker H (2011) Serine racemase and the serine shuttle between neurons and astrocytes. Biochim Biophys Acta 1814:1558-1566. CrossRef Medline

Zuckerman L, Rehavi M, Nachman R, Weiner I (2003) Immune activation during pregnancy in rats leads to a postpubertal emergence of disrupted latent inhibition, dopaminergic hyperfunction, and altered limbic morphology in the offspring: a novel neurodevelopmental model of schizophrenia. Neuropsychopharmacology 28:1778-1789. CrossRef Medline 